\title{
Peran Guru dalam Menstimulasi Kemampuan Menggambar pada Anak Usia Dini di Raudhatul Athfal Kuningan Jawa Barat
}

\author{
Nurlailla ${ }^{1}$ Maulidya Ulfah ${ }^{2}$ Ahmad Yani ${ }^{3}$ \\ Dosen PGRA IAIN Syekh Nurjarti Cirebon ${ }^{1} 23$ \\ ellalailla665@yahoo.co.id 1 ulfah.003@yahoo.com ${ }^{2}$ ahmadhabib75@yahoo.co.id $^{3}$
}

Kegiatan Menggambar merupakan salah satu bentuk pembelajaran aspek perkembangan anak usia dini. Kegiatan ini diterapkan di RA Qurrata A'yun Kuningan. Kegiatan ini dapat berjalan lancar dengan diberikannya stimulus oleh pendidik, untuk itu guru harus memiliki standar kreatif dan kemampuan kompetensi sebagai pendidik anak usia dini yang profesional. Penelitian ini dilatar belakangi oleh guru yang mengalami kesulitan dalam mengelola kelas dan kepercayaan diri anak terhadap hasil karya menggambar. Penelitian ini bertujuan untuk meningkatkan kreatifitas dalam pengembangan seni dan motorik halus anak. Jenis penelitian adalah dekriptif kualitatif. Subjek adalah anak di RA Qurrata A'yun Kuningan. Cara yang digunakan untuk mengumpulkan data ini menggunakan observasi, wawancara dan dokumentasi. Hasil penelitian menunjukan bahwa peran guru dalam menstimulasi kemampuan menggambar pada anak yaitu sebagai sember belajar, pengelola, fasilitator, pengelola, demonstrator, pembimbing, motivator, evaluator, mediator. Terbukti dari hasil penilaian guru dari pengawas dengan keterangan baik, penilaian tersebut diperoleh dari proses pembelajaran sehari-hari guru yang telah diamati oleh pengawas madrasah. Proses kegiatan menggambar pada anak mendapatkan hasil dengan baik dalam bidang kompetensi seni. Dapat disimpulkan bahwa dengan adanya peran guru yang sesuai maka akan tercapainya tingkat capaian perkembangan anak khususnya dalam proses kegiatan menggambar pada aspek perkembangan seni, motorik terhadap apa yang dilihat dan diketahui yang akan diekspresikan melalui seni gambar pada anak usia dini

Kata Kunci: guru, stimulus, menggambar dan anak usia dini

Drawing Activities is one form of learning that serve as aspects of early childhood development. This activity is often applied in RA Qurrata A'yun Kuningan. Drawing activities can run smoothly with stimulus provided by educators, so it is important for teachers to have a standard as a teacher who has creativity and has the ability to compete as a professional early childhood educator. This research is motivated by teachers who have difficulty in conditioning class, problems in this activity often occur because of lack of spirit and confidence of children to the work of drawing. This study aims to increase creativity in the development of children's talent interest in children's fine motor The type of research used is qualitative descriptive. Subjects in this study were children in RA Qurrata A'yun Kuningan. The means used to collect this using Observation techniques, interviews and documentation. The results of the research have shown that the role of teachers in stimulating children's drawing ability, they have role as learning seminar, manager, facilitator, manager, demonstrator, mentor, motivator, evaluator, mediator. Evident from the results of the teacher's assessment of the supervisor with a description of Good, the assessment is derived from the daily learning process of teacher which has been observed by the madrasah supervisor. From the results of the observed research, in the process of drawing activity in the children get the results well in the field of art competence. Although, among them there are some children who still find it difficult in drawing. But it can be concluded with the role of appropriate early childhood teachers will achieve the level of child development achievement, especially in the process of drawing activities to support the development of aspects of the development of art, motor and knowledge of what is seen and known that will be expressed through the art images in early childhood.

Keywords: teacher, stimulate, drawing and early childhood 


\section{PENDAHULUAN}

Peran guru di sekolah tentunya pasti memberikan pendidikan yang sesuai dengan tumbuh kembangnya, seperti dalam hal nya kegiatan menggambar. Dimana Guru berharap anak usia dini dapat mengikuti kegiatan menggambar sesuai yang ditugaskan. Untuk itu perlu dibutuhkannya peran guru yang sudah mengerti tentang pentingnya pendidikan karakter anak usia dini dan mengetahui kebutuhan untuk aspek tumbuh kembang anak.

Namun berdasarkan observasi awal yang dilakukan di RA Qurrata A'yun Kuningan oleh peneliti masih menemukan permasalahan ketika hendak memulai kegiatan pembelajaran, guru merasa kesulitan untuk mengelola kelas, sehingga keadaan kelaspun tidak terkondisikan dengan baik, akibatnya suasana kelas menjadi gaduh dan anak tidak berkonsentrasi pada saat kegiatan berlangsung. Pembelajaran di kelas yang lebih memfokuskan pada baca tulis dan hitung, mengakibatkan anak kurang tertarik dalam menerima pembelajaran seni terutama dalam seni menggambar, padahal seharusnya anak dapat mencapai aspek perkembangan dalam bidang seni, sesuai dengan usianya yaitu 5-6 tahun (Suyadi, 2013).

Mengetahui persoalan tersebut peneliti merasa perlu membahas permasalahan ini dan seperti apa peran guru yang seharusnya di berikan terhadap siswa anak usia dini, agar anak lebih bisa menyukai dan berantusias dalam menggambar sehingga aspek perkembangan dalam bidang seni khususnya kegiatan menggambar dapat tercapai sesuai dengan tingkat pencapaian perkembangan anak. Tentunya permasalahan tersebut tidak terlepas dari faktor-faktor yang memepengaruhi proses pembelajaran yang dapat mendukung untuk berjalannya proses pembelajaran kegiatan menggambar, selain itu terdapat juga faktor penghambat yang terdapat di RA Qurrata A'yun Kuningan pada proses kegiatan menggambar.

\section{KAJIAN TEORI}

Guru adalah sosok sentral bagi kepribadian anak didik. Mereka mendengar ucapan dan meneladani perilaku guru mereka. Dalam konteks penggalian dan pengembangan bakat anak didik, peran guru sangat mencolok. Tentu kita menginginkan guru-guru sekarang mampu mengenal bakat anak didik mereka dan mengarahkan ke tempat yang benar. Memang, pada zaman dahulu, guru mampu membuka tirai anak didiknya, sehingga mereka terbukan mata hatinya menuju tangga kesuksesan dunia-akhirat (Jamal, 2012: 111).

Guru Pendidikan anak usia dini merupakan pengalaman yang menyenangkan bagi semua yang membidangi profesi ini dan memberikan layanan yang memuaskan (Yufiarti, 2010:16). Menurut Helen Parkhurst setiap guru haruslah seorang ahli yang menguasai dan mencintai bidang studi masing-masing. Setiap guru harus memiliki kompetensi dalam memberi penjelasan secara umum pada anak-anak yang mengunjungi bidang studinya sesuai dengan topik/pokok bahasan yang akan dipelajari anak-anak. Selain itu guru harus berusaha memperhatikan dan mengamati pekerjaan setiap anak, menanyakan kesulitan yang dialami, memberikan bimbingan sehingga anak benar-benar menguasai tersebut, guru juga memberikan arahan ketika anak menggunakan berbagai alat untuk mengkaji suatu bahan tertentu, guru harus mengetahui perkembangan setiap anak dalam mengerjakan berbagai tugas, sehingga dapat mengikuti tempo dan irama perkembangan anak dalam menguasai bahan pembelajaran (Yuliani, 2013:111). Dalam buku Yuliani (2013:62) Catron dan Allen (1999:23-26) menyebutkan bahwa terdapat 6 (enam) aspek perkembangan anak usia dini, yaitu kesadaran personal, kesehatan emosional, sosialisasi, komunikasi, kognisi dan keterampilan motorik sangat penting dan harus dipertimbangkan sebagai fungsi interaksi. Kreatifitas tidak dipandang 
sebagai perkembangan tambahan, melainkan sebagai komponen yang integral dari lingkungan bermain yang kreatif (Hurlock, 1980).

Dalam perkembangan anak usia dini sudah mencapai tahap pembelajaran kegiatan gambar. Hal ini di dukung oleh teori Friederich Wilhelm Froebel (1782-1852) dalam Buku Soemiarti (2003:6) Menurut Froebel, guru bertanggung jawab dalam membimbing dan mengarahkan, dengan demikian anak menjadi kreatif dan akan menyumbangkannya kepada masyarakatnya. Masnipal (2013:225) usaha dan kerja keras atau determinasi lingkungan adalah faktor yang mempunyai pengaruh lebih besar dibandingkan dengan faktor bawaan untuk mengembangkan kemampuan berfikir kreatif. Hal ini dapat berarti bahwa individu memiliki peluang dan kesempatan lebih terbuka untuk mengembangkan kreativitasnya melalui kegiatan-kegiatan yang diusahakan secara sengaja. Seni kreativitas merupakan suatu proses dan sekaligus hasil belajar yang disengaja dan disadari. Sebagai proses yang disadari maka kreativitas dapat dipelajari dan dikembangkan melalui intervensi pendidikan dan bimbingan, termasuk bimbingan melalui kegiatan bermain. Pengembangan seni kreativitas juga berpengaruh kepada prestasi akademik individu. Jamal (2012:132) kegiatan menggali dan mengembangkan bakat anak di sekolah sering kali berhadapan dengan berbagai persoalan atau penghambat yaiutu sempitnya wawasan, tidak ada good will, hilangnya kekuatan kekuatan visi dan misi, sulitnya mencari pembimbing ahli.

\section{METODE}

Pada penelitian ini, peneliti menggunakan penelitian kualitatif deskriptif yaitu rumusan masalah yang memandu peneliti untuk mengeksplorasi dan memotret situasi sosial yang akan diteliti secara menyeluruh, luas dan mendalam. Dari penelitian ini penelitian akan memporoleh data sesuai rumusan masalah dimana penelitian ini akan mengungkap bagaimana deskripsi peran guru dalam menstimulasi kemampuan menggambar pada anak di RA Qurrata A'yun Kecamatan Cigugur Kabupaten Kuningan. Peneliti akan memperoleh data dari berbagai sumber yang di percaya, yaitu data primer sumber data ini berdasarkan hasil yang di peroleh dari lokasi penelitian RA Qurrata A'yun Kuningan dengan wawancara, mencatat merekam seputar peran guru menstimulasi kemampuan menggambar pada anak wali kelas dan guru.

Sedangkan sumber data sekunder di dapat berdasarkan teori dari buku-buku dan ebook yang berkaitan peran guru, anak usia dini, menggambar serta adokumen dan arsip yang menunjang informasi yang akurat dalam peran guru menstimulasi kemampuan menggambar pada anak dan kepala sekolah RA Qurrata A'yun Kabupaten Kuningan serta guru.

Dalam Rully dkk (2014:112) instrumen penelitian yang merupakan alat bagi peneliti yang relevan dengan permasalahan penelitian. Untuk itu peneliti berperan sebagai instrumen penelitian. Instrumen yang digunakan oleh peneliti dalam peran guru dalam menstimulasi kegiatan menggambar pada anak di RA Qurrata A'yun Kabupaten Kuningan dengan menggunakan catatan wawancara, catatan lapangan dan di perkuat dengan catatan dokumentasi. Semua itu didapat oleh peneliti pada saat melakukan observasi di sekolah, dimana disetiap kejadian kegiatan proses pembelajaran di tulis kemudian akan di analsis.

Untuk mengumpulkan data, penelitian menggunakan teknik wawancara dengan pihak sekolah, observasi untuk melihat langsung keadaan tempat observasi dan diperkuat dengan dokumentasi yang berupa arsip-arsip dan poto dokumentasi di RA Qurrata A'yun Kuningan. Setelah data terkumpul, data yang didapat akan dinalisa oleh peneliti. Menurut Sugiyono (2013:335) analisis data adalah proses mencari dan menyusun secara sistematis data yang diperoleh dari hasil wawancara, catatan lapangan, 
dan dokumentasi, dengan cara mengorganisasikan data kedalam kategori, menjabarkan kedalam unitunit, melakukan sintesa menyusun kedalam pola, memilih mana yang penting dan yang akan dipelajari dan membuat kesimpulan sehingga mudah dipahami oleh diri sendiri maupun orang lain. Teknik keabsahan data dalam penelitian ini dilakukan untuk membuktikan hasil penelitian dengan kenyataan yang diteliti di lapangan. Pemeriksaan keabsahan data didasarkan atas kriteria. Triangulasi adalah teknik pemeriksaan keabsahan data yang memanfaatkan sesuatu yang lain. Di luar data itu untuk keperluan pengecekan atau sebagai pembanding terhadap data itu. Teknik triangulasi yang paling banyak digunakan ialah pemeriksaan melalui sumber lainnya. Menurut Moleong (2009:335) Triangulasi adalah teknik pemerikasaan keabsahan data yang memanfaatkan sesuatu yang lain di luar data yang ada untuk keperluan pengecekan atau pembanding terhadap data tersebut.

\section{HASIL PENELITIAN}

Hasil penelitian yang didapat oleh peniliti guru di RA Qurrata A'yun Kuningan yaitu terdapat 5 guru lulusan sarjana. Tiga guru diantaranya merupakan sarjana PAUD dan guru lainnya lulusan sarjana PAI dan ekonomi. Adapun data murid di RA Qurrata A'yun Kuningan yang terdiri dari 3 kelas, yaitu : kelas A terdapat 16 murid, kelas B1 terdapat 25 murid, sedangkan di kelas B2 terdapat 28 murid. Jika dijumlahkan semua maka terdapat 69 murid.

\section{Peran Guru Dalam kegiatan Menggambar}

Peneliti melihat bahwa stimulasi dalam kegiatan menggambar terdapat di dalam peran guru RA Qurrata Ayun yaitu sebagai berikut :

\section{Guru sebagai Sumber Belajar}

Pada praktiknya guru di RA Qurrata A'yun telah menguasai materi pembelajaran yang akan disampaikan sesuai dengan tema materi pembelajarannya khususnya untuk kegiatan menggambar. ketika ada anak yang bertanya mengenai pembelajaran seputar kegiatan menggambar, guru dapat merespon dengan benar dan dapat dipahami oleh anak, peran guru sebagai sumber belajar di RA Qurrata A'yun telah membantu proses pembelajarn khususnya dalam kegiatan menggambar.

\section{Guru sebagai Fasilitator}

Peran guru sebagai fasilitator di RA Qurrata A'yun untuk mendampingi anak usia dini agar dapat memudahkan dalam proses pembelajaran kegiatan menggambar. Sebagai pendamping anak usia dini guru di RA Qurrat A'yun menghadapi anak dengan sabar dan terus memotivasi sampai anak dapat mengerjakan tugas menggambar. Peneliti melihat ketika dalam proses pembelajaran kegiatan menggambar, guru RA Qurrata A'yun sangat sabar dan mengayomi anak ketika anak mengalami kesulitan dalam belajar, dengan kesabarannya guru terus mendampingi anak sampai anak mampu mengerjakan tugas sampai dengan benar dan selesai.

\section{Guru sebagai Pengelola}

Peneliti mengamati pengelolaan guru di RA Qurrata A'yun masih merasakan kesulitan, disini terlihat karena jumlah anak dan guru tidak sesuai dengan rasio yang ditetapkan. Jumlah di kelompok B terdiri dari 25 jumlah anak sedangkan dalam peraturan permendikbud standarisasi pengelola guru 1:15 anak (Permendikbud No 137 tahun 2013). Dalam pelaksanaannya di kelas, guru mempunyai strategi untuk mengelola kelas yaitu dengan cara mengajak anak untuk tertib sebelum memulai pembelajaran dan mengajak anak fokus pada ibu guru di depan kelas dengan bernyanyi dan tepukan. 


\section{Cross Check dengan Hasil Wawancara}

Hal ini selaras dengan hasil wawancara dengan Ibu Hani (22 maret 2017). Sebelum masuk dalam proses pembelajaran guru RA Qurrata A'yun terlebih dahulu mengkondisikan kelas, mengalihkan perhatian anak pada pembelajaran yang akan diberikan agar anak fokus dan memahami apa yang di sampaikan oleh guru.

\section{Guru sebagai Demonstrator}

Perannya sebagai demonstrator, guru di RA Qurrata A'yun pintar dalam bersikap terhadap anak usia dini, karena anak dapat mengerti dan memahami atas apa yang disampaikan dalam pemberian materi dan pemberian tugas kegiatan menggambar di kelas. Peneliti melihat guru di RA Qurrata A'yun menunujukan sifat yang baik dan positif pada anak, karena merupakan peniru ulung terhadap apa yang dilihat dan dengar, untuk itu sebagai guru yang profesional harus menjaga tingkah laku dan memiliki sikap terpuji yang akan dilihat oleh anak usia dini maupun orang tua dan masyarakat sekitar (Saifuddin, 2013).

\section{Guru sebagai Pembimbing}

Guru RA Qurrata A'yun mengarahkan dan memberi motivasi anak usia dini dengan sabar dan penuh keyakinan optimis bahwa anak dapat dapat mengikuti proses pembelajaran khususnya untuk kegiatan menggambar dengan baik. Tidak hanya itu, guru bisa memahami apa yang dibutuhkan oleh anak usia dini untuk tumbuh kembangnya, dalam mencapai aspek perkembangannya. Ketika di lapangan Guru RA Qurrata A'yun memiliki kesabaran dalam membimbing anak didiknya, dengan lemah lembut anak terus diarahkan dalam megembangkan minat belajarnya terhadap materi yang diberikan ketika kegiatan menggambar.

Guru sebagai Motivator.

Agar mendapat hasil yang optimal dalam pembelajaran, guru RA Qurrata A'yu pintar memberi semanagat dan motivasi dalam belajar, agar anak lebih antusias untuk mengerjakan tugas dan bisa mendapatkan hasil yang baik dalam pembelajaran. Dalam prakteknya, guru RA Qurrata A'yun setiap sebelum pembelajaran selalu memberikan semangat dan stimulasi anak agar bisa mengikuti pembelajaran kegiatan menggambar dan menyelesaikan tugas dengan sesuai, adapun ada anak yang terlihat kurang semangat dan terlihat murung ibu guru akan mengahampiri, memotivasi dan menyemangati untuk mengajak anak belajar dengan perasaan senang dan gembira.

\section{Guru sebagai Evaluator.}

Peran lain guru di RA Qurrata A'yun adalah evaluator, yaitu mengumpulkan dan melihat hasil proses kemampuan pembelajaran kegiatan menggambar yang telah dilakukan. Dalam penilaian untuk anak usia dini, tidak menggunakan dengan angka namun dengan menggunakan simbol bintang ataupun senyum dan diakhiri dengan penilaian di akhir semester dan tahun atau buku rapor yang penilaiannya mendeskripsikan semua hasil proses pembelajaran khususnya kegiatan menggambar. Seperti halnya di RA Qurrata A’yun guru disana menggunakan simbol bintang dan senyum untuk penilainnya.

\section{Guru sebagai Mediator}

Dalam pembelajarannya, guru RA Qurrata A'yun menjadi mediator yang baik pemberi stimulus pembelajaran ketika berinteraksi dengan anak didik tujuannya agar anak paham terhadap pembelajaran yang ibu sampaikan dan bisa mengerjakan tugas kegiatan menggambar yang diberikan oleh guru. 


\section{DISKUSI}

Peneliti berpendapat bahwa dalam setiap penampilan guru harus baik, positif karena sekolah merupakan rumah kedua anak usia dini dan guru pun sebagai peran orang tua kedua ketika berada diluar rumah khususnya disekolah yang dipercaya untuk pendidikan membentuk anak yang memiliki potensi dan generasi baik di masa yang akan datang. Hasil gambar anak memiliki ekspresi alami yang berbeda dalam hal seni gambar, tentunya dari kegiatan menggambar ada peran sebagai guru untuk menstimulasi kemampuan anak dalam seni gambar sehingga anak dapat mengembangkan aspek perkembangannya dalam bidang seni khususnya dalam seni gambar. Penilaian untuk anak di RA Qurrata A'yun Kuningan dilakukan dalam kurun waktu mingguan dan persemester sesuai dengan pedoman penilaian yang telah ditetapkan (Pedoman penilaian, 2015). Faktor Penghambat dan Pendukung dalam kegiatan menggambar RA Qurrata A'yun Kuningan Adapun faktor penghambat dalam proses pembelajaran kegiatan menggambar antara lain alat peraga dalam kegiatan menggambar seadanya. Dengan fasilitas seadanya kegiatan menggambar tetap dilakukan, yaitu: papan tulis, spidol, gambar seadanya. Sedangkan fasilitas yang dimiliki anak adalah pensil, buku gambar, penghapus, pensil warna, spidol dan lain sebagainya. Namun, terkadang dalam proses pembelajarannya ada anak yang tidak membawa perlengkapan menggambar, seperti salah satu anak didik yang lupa membawa pensil dan buku gambar yang sudah penuh dengan gambar lain sehingga tidak ada lembaran kosong untuk menggambar lagi, setelah peneliti mengamati faktor tersebut disebabkan oleh kurangnya komunikasi antara anak dengan orang tua dalam keperluan fasilitas untuk menggambar. Jadi, orang tua kurang peka dalam memperhatikan terhadap pemenuhan fasilitas terutama kegiatan menggambar.

Selain faktor penghambat diatas, terdapat faktor lain yaitu jumlah anak di di kelas ada 25 anak. Hal ini tidak sesuai standar yang telah ditetapkan oleh Permendikbud dengan rasio satu orang guru membimbing 15 anak. Walaupun begitu guru tetap memberikan pembelajaran yang terbaik untuk anak didiknya. Faktor selanjutnya adalah orang tua yang ikut menemani anak di dalam kelas, karena ketika ditinggal anak itu menagis dan tidak ingin mengikuti proses pembelajaran. Sedangkan Faktor pendukung menurut Masnipal (2013:225) usaha dan kerja keras atau determinasi lingkungan adalah faktor yang mempunyai pengaruh lebih besar dibandingkan dengan faktor bawaan untuk mengembangkan kemampuan berfikir kreatif. Hal ini dapat berarti bahwa individu memiliki peluang dan kesempatan lebih terbuka untuk mengembangkan kreativitasnya melalui kegiatan-kegiatan yang diusahakan secara sengaja.

Faktor pendukung dalam kegiatan menggambar di RA Qurrata A'yun Kuningan, antara lain :

\section{Dukungan Orang Tua}

Adanya dukungan orang tua, anak usia dini dapat mengerjakan tugas kegiatan menggambar.

\section{Peran Guru dalam Pembelajaran}

Peran guru di RA Qurrata A'yun Kuningan yang memiliki sifat sabar dan terus membimbing anak usia dini dalam menyelesaikan tugas kegiatan menggambar.

Minat belajar anak dalam kegiatan menggambar membantu berjalannya proses pembelajaran kegiatan anak sesuai dengan yang diharapkan.

\section{KESIMPULAN}

Peran guru di RA Qurrata A'yun Kuningan sudah memenuhi perannya yaitu guru sebagai sumber belajar, guru sebagai fasilitator, guru sebagai pengelola, guru sebagai demonstrator, guru sebagai pembimbing, guru sebagai motivator, guru sebagai evaluator, guru sebagai mediator. Standarisasi pendidikan dan tenaga kependidikan guru di RA Qurrata A'yun telah dikatakan memenuhi kualifikasi akademik guru PAUD. Peran guru mendapat penilaian terhadap kinerjanya dalam proses pembelajaran, yang dilakukan oleh pengawas sekolah. 
Hasil penilaian tugas anak dalam Kegiatan menggambar, rata-rata anak mampu mengerjakan tugas menggambar sesuai yang ditugaskan oleh guru, dalam evaluasi akhir semester rata-rata anak mendapat penilaian Baik di bidang kompetensi seni. Faktor pendukung dan penghambat dalam kegiatan menggambar di RA Qurrata A'yun Kuningan mempengaruhi proses berlangsungnya kegiatan menggambar, yaitu: (1) faktor penghambat : alat peraga yang digunakan oleh guru dalam kegiatan menggambar belum memadai, jumlah yang tidak sesuai dengan standar Permendikbud bahwa satu orang guru membimbing 15 anak dan orang tua yang ikut masuk kelas, (2) faktor pendukung : adanya dukungan orang tua, peran guru di RA Qurrata A'yun Kuningan, minat belajar anak dalam kegiatan menggambar membantu berjalannya proses pembelajaran kegiatan anak sesuai dengan yang diharapkan.

\section{REFERENSI}

Hurlock, EB. (1980). Perkembangan Anak Jilid II (Alih Bahasa : Meitasari Tjandrasa). Jakarta : Penerbit Erlangga.

Jamal. (2012). Kiat Mengembangkan Bakat Anak di Sekolah. Yogyakarta: Diva Press.

Masnipal. (2013). Siap Menjadi Guru dan Pengelola PAUD Profesional. Jakarta : PT Elex Media Komputindo.

Lexy J. Moleong. (2009). Metode Penelitian Kualitatif. Edisi Revisi. Bandung : Remaja Rosdakarya.

Permendikbud Nomor 137 Tahun 2014.

Kemedikbud. (2015). Pedoman Penilaian Pembelajaran Pendidikan Anak Usia Dini. Jakarta: Pembinaan Pendidikan Anak Usia Dini.

Rully, Poppy. (2014). Metodologi Penelitian. Bandung: PT Refika Aditama.

Saifuddin. (2014). Pengelolaan Pembelajaran Teoritis Dan Praktis. Yogyakarta: Deepublish.

Sugiyono. (2011). Metode Penelitian Kuantitatif Kualitatif dan R\&D. Bandung: Alfabeta.

Suyadi, Maulidya Ulfah. (2013). Konsep Dasar PAUD, Bandung : PT Remaja Rosdakarya

Yuniarti \& Titi Chandrawati, (2011). Profesionalitas Guru PAUD. Jakarta: Universitas Terbuka.

Yuliani (2013). Konsep Dasar PAUD. Bandung : PT. Rajagrafindo Persada. 